\title{
The Effect of Job Stress and Organizational Climate on Turnover Intention Through Job Satisfaction of Sales Employees PT XYZ Distribution in West Jakarta
}

\author{
Tyas Setyorini ${ }^{1}$, Charles Bohlen Purba ${ }^{2}$ \\ ${ }^{1}$ Master of Management, Mercubuana University, Jakarta, Indonesia \\ ${ }^{2}$ Lecturer of Postgraduate, Mercubuana University, Jakarta, Indonesia
}

\begin{abstract}
This study aims to determine and analyze the effect of work stress and organizational climate on turnover intention through job satisfaction of sales employees of PT. XYZ distribution in West Jakarta. This research method uses quantitative research. The population in this study were all sales employees of PT. XYZ distribution in West Jakarta. The sample used in this study uses probability sampling techniques by means of sampling the simple random sampling method. Then the sample size used in this study were 279 sales employees. The data analysis method used in this study was path analysis with the help of the SPSS version 25.0 program. The results showed that job stress has a negative and significant effect on job satisfaction. Organizational climate has a positive and significant effect on job satisfaction. Job stress has a positive and significant effect on turnover intention. Organizational climate has a negative and significant effect on turnover intention. Job satisfaction has a negative and significant effect on turnover intention. Job stress on turnover intention through job satisfaction has a positive and significant effect. And organizational climate on turnover intention through job satisfaction has a positive and significant effect.
\end{abstract}

Keywords:- Job Stress, Organizational Climate, Turnover Intention, Job Satisfaction.

\section{INTRODUCTION}

The existence of human resources contributes and influences the company's competitive success. And the existence of reliable human resources has a very important role too. Aware will importance of human resources for the survival and progress of a company then a company should give special attention to this aspect. One problem that affects the workforce in a company is the high turnover rate. For example, the sales employee of PT. XYZ distribution in West Jakarta has a fluctuating turnover intention in 2016-2018.

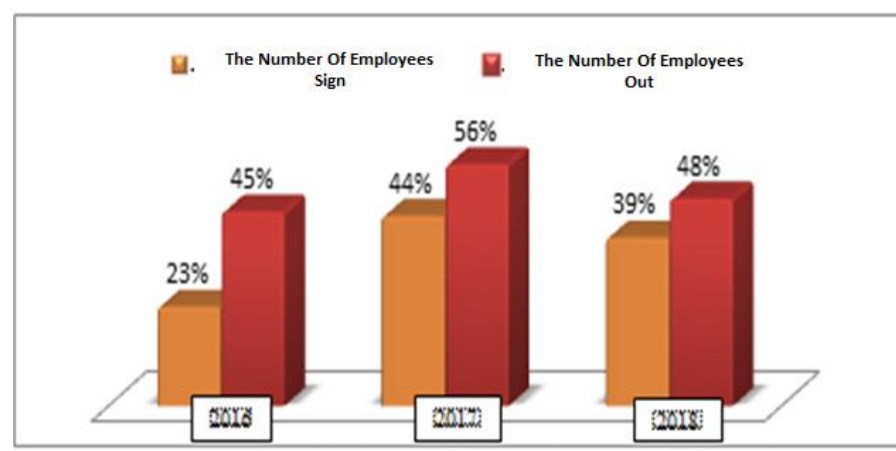

Fig 1:- Data Turnover Employees Division Sales PT XYZ Distribution in West Jakarta 2016-2018

Source: HRD PT XYZ Distribution in West Jakarta 2019

Figure 1 shows that the turnover rate at PT XYZ Distrubsi in Wet Jakarta is categorized as quite high with data that fluctuates every year. It was recorded that in 2016 the turnover rate was $45 \%$ with $23 \%$ employees, in 2017 the turnover rate had increased by $56 \%$ and the number of incoming employees also increased by $44 \%$ compared to 2016 where the number of employees was not many. In 2018 the turnover rate was $48 \%$, which can be seen that the turnover rate fell from the previous year which experienced an increase in 2 consecutive years, and in 2018 for incoming employees also decreased by $39 \%$.

Based on Figure 1 regarding turnover intention, the researcher conducted a pre-survey related to what factors affect the turnover intention rate of PT XYZ Distribution employees in West Jakarta and these factors are organizational climate, leadership style, work motivation, work stress, compensation, organizational culture, work environment and job satisfaction. Based on the results of the pre-survey conducted by researchers, it is known that from several factors that survey researchers, there are three highest factors that affect turnover intention, namely job satisfaction by $26 \%$, job stress by $20 \%$, and organizational climate by $16 \%$. And henceforth, the three variables are used as choice variables to examine how the relationship with turnover intention at PT XYZ Distribution in West Jakarta. 
ISSN No:-2456-2165

This is also confirmed by the results of presurvey interviews / observations of the 30 employees of the division of Sales at PT XYZ Distribution in West Jakarta, which is done in order to get an overview of the situation and working conditions perceived division Sales, primarily related to job stress, organizational climate, job satisfaction, and turnover intention as shown in the following table.

\begin{tabular}{|c|c|c|c|c|c|c|c|c|}
\hline No. & Statement & STS & TS & N & S & SS & $\begin{array}{c}\text { Total Score } \\
\begin{array}{c}\text { Average Score } \\
(\%)\end{array}\end{array}$ \\
\hline 1. & $\begin{array}{c}\text { The target set by the company is too } \\
\text { high }\end{array}$ & 0 & 11 & 5 & 12 & 2 & 95 & $31.67 \%$ \\
\hline 2. & I feel bored with the work I have & 1 & 14 & 3 & 8 & 4 & 90 & $30.00 \%$ \\
\hline 3. & $\begin{array}{c}\text { The work I do at this company } \\
\text { doesn't match my skills }\end{array}$ & 4 & 6 & 3 & 15 & 1 & 90 & $30.00 \%$ \\
\hline
\end{tabular}

Table 1: - Pre-Job Stress Survey Results

Source: Researcher Processed Data, 2019

Based on table 1 in the direct pre-survey, it is known that employees experience very high job stress at the target stage of the company which they give is too high with a total average score of $31.67 \%$. Then also employees feel bored with their own work and many employees who work in the company do not match the skills they have.

\begin{tabular}{|c|c|c|c|c|c|c|c|c|}
\hline No & Statement & STS & TS & N & S & SS & Total Score & $\begin{array}{c}\text { Average Score } \\
(\%)\end{array}$ \\
\hline 1. & $\begin{array}{c}\text { I get more rewarded if I can } \\
\text { complete assignments well }\end{array}$ & 0 & 8 & 4 & 13 & 5 & 105 & $35.00 \%$ \\
\hline 2. & $\begin{array}{c}\text { My roles and responsibilities in } \\
\text { the organization are clearly } \\
\text { exposed in the company }\end{array}$ & 4 & 10 & 7 & 3 & 6 & 87 & $29.00 \%$ \\
\hline 3. & $\begin{array}{c}\text { The organization in the company } \\
\text { is very clear }\end{array}$ & 8 & 2 & 3 & 12 & 4 & 89 & $29.67 \%$ \\
\hline
\end{tabular}

Table 2: - Organizational Climate Pre-Survey Results

Source : Researcher Processed Data, 2019

Based on table 2 of the results of the pre-organizational climate survey, it is known that the highest average score is $35.00 \%$ in statement number one, which means that the company does not give more rewards to employees who complete their tasks well.

\begin{tabular}{|c|c|c|c|c|c|c|c|c|}
\hline No & Statement & STS & TS & N & S & SS & Total Score & Average Score (\%) \\
\hline 1. & $\begin{array}{c}\text { Lack of career paths in the } \\
\text { company }\end{array}$ & 0 & 10 & 4 & 6 & 10 & 106 & $35.33 \%$ \\
\hline 2. & Clear organization & 5 & 8 & 5 & 8 & 4 & 88 & $29.33 \%$ \\
\hline 3. & $\begin{array}{c}\text { I feel that my reward is } \\
\text { received fairly and in } \\
\text { accordance with my needs }\end{array}$ & 15 & 7 & 3 & 4 & 1 & 59 & $19.67 \%$ \\
\hline
\end{tabular}

Table 3: - Pre-Job Satisfaction Survey Results

Source: Researcher Processed Data, 2019

Based on table 3 the results of the pre-job satisfaction survey the highest average score is $35.33 \%$, which is less good for the career path in the company. Even though the organization in the company is already good, it is less for the employees for their careers.

\begin{tabular}{|c|c|c|c|c|c|c|c|c|}
\hline No & Statement & STS & TS & N & S & SS & Total Score & $\begin{array}{c}\text { Average Score } \\
(\%)\end{array}$ \\
\hline 1. & $\begin{array}{c}\text { I often seek information } \\
\text { about other jobs }\end{array}$ & 0 & 12 & 4 & 11 & 3 & 89 & $29.67 \%$ \\
\hline 2. & $\begin{array}{c}\text { I am thinking of quitting } \\
\text { my job }\end{array}$ & 1 & 10 & 7 & 11 & 1 & 91 & $30.33 \%$ \\
\hline 3. & $\begin{array}{c}\text { I intend to leave this } \\
\text { company because my } \\
\text { work is too heavy }\end{array}$ & 4 & 6 & 3 & 15 & 1 & 96 & $32.00 \%$ \\
\hline
\end{tabular}

Table 4: - Turnover Intention Pre-Survey Results

Source: Researcher Processed Data, 2019 
Based on table 4 of the results of the pre-turnover intention survey, it can be seen that the highest average score is $32.00 \%$ in question number three, employees who want to intend to leave the company because the work in the company is too heavy. Then also employees think about quitting the job.

\section{THEORETICAL REVIEW}

\section{A. Job Stress}

According Luthans (2008: 32 ) stress as a response in adjusting influenced by individual differences and psychological processes, as a consequence of environmental action, a situation or event that is too much to hold one's psychological and physical demands. Furthermore, according to Tantra and Larasat (2015), in general, the causes of stress are intrinsic to work, including physical demands such as noise, vibration and hygiene, while the task demands include shift work / night work, workload, working conditions that use little physical activity, time. narrow work and appreciation of job risks.

\section{B. Organizational Climate}

According to Robert Stinger in Wirawan (2007: 64) i claim organsisasi as a collection and environmental trends that determine the appearance of motivation and focusing on perception - the perception that it makes sense or can be assessed, so as to have a direct influence on the performance of members of the organization. Furthermore, according to Taiguri and Litwin in Wirawan (2007: 65), organizational climate is a relatively continuous quality of the internal environment of the organization, experienced by members of the organization and influencing their behavior and can be described in a set of organizational characteristics or characteristics. The quality of this organizational environment is experienced by employees in the organization in the form of values, characteristics or characteristics of the organization.

\section{Job Satisfaction}

According to Malayu (2011: 44) job satisfaction is a pleasant emotional attitude and loves her job. This attitude is reflected by work morale, discipline, and work performance. Furthermore, according to Robbins and Judge (2008), the term job satisfaction refers to the general attitude of an individual towards his job. A person with a high level of job satisfaction shows a positive attitude towards the job; a person who is dissatisfied with his job shows a negative attitude towards that work.

\section{Turnover Intention}

Melky (2015) turnover intention is an employee's desire and desire to quit membership in the organization and change jobs by receiving income wages. This opinion shows that turnover intention is the desire to move, not yet at the realization stage, which is to move from one workplace to another. Furthermore, according to Norita (2014) turnover intention is the desire or intention of an individual with full consideration and consciously to find an alternative job by leaving the company where he is currently working for another company.

\section{E. Framework}

Based on a study of the above theories and previous research on the effect of work stress and organizational climate on turnover intention through job satisfaction, the framework in this study is as follows:

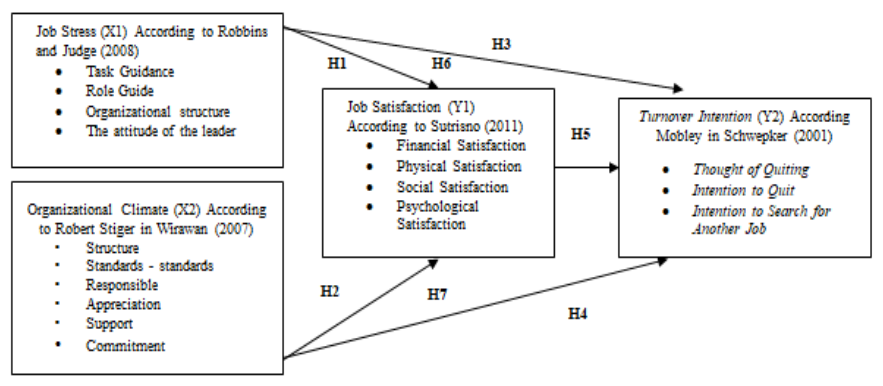

Fig 2: - Framework

\section{F. Hypothesis}

Based on the description of the framework above, the hypothesis in this study is as follows:

$>\mathrm{H} 1$ : There is an effect of job stress (X1) on job satisfaction (Y1) in sales employees of PT XYZ Distribution in West Jakarta.

$>\mathrm{H} 2$ : There is an influence of organizational climate (X2) on job satisfaction (Y1 ) in sales employees of PT XYZ Distribution in West Jakarta.

$>\mathrm{H} 3$ : There is job stress (X1) on turnover intention (Y2) for sales employees of PT XYZ Distribution in West Jakarta.

H4: There is an organizational climate (X2) on turnover intention (Y2) for sales employees of PT XYZ Distribution in West Jakarta.

$>$ H5: There is an effect of job satisfaction ( Y1) on turnover intention (Y2) for sales employees of PT XYZ Distribution in West Jakarta.

$>$ H6: There is an effect of job stress (X1) on turnover intention (Y2) through job satisfaction (Y1 ) on sales employees of PT XYZ Distribution in West Jakarta.

$>$ H7: There is an influence of organizational climate (X2), there is turnover intention (Y2) through job satisfaction (Y1) for sales employees of PT XYZ Distribution in West Jakarta.

\section{METHODOLOGY}

\section{A. Type of Research}

The type of data used in this research is quantitative data with data obtained from direct survey respondents through questionnaires. To mudian data is quantified by giving a score or number on each of the respondents. Therefore, researchers use a tool called a measurement scale (Likert scale). Answers to questionnaires given to a sample, then be analyzed to take into account the influence of the independent variables in order to obtain accurate data on the facts and their influence between va riabel research with Path Analysis. 


\section{B. Population and Sample}

$\mathrm{P}$ opulation in this study were all sales employees of PT XYZ Distribution in West Jakarta with a total of 921 employees. The sample used as the object of the study was determined based on the calculation of the slovin formula, with a tolerable error level of $5 \%$. So from the above conclusions, the sample in this study was 279 employees. Determination of respondents selected using probability sampling techniques in which the sampling method is simple random sampling by taking members of the sample from the population is done randomly without considering the existing strata in the population .

\section{Data Collection Methods}

In this study, the data collection method uses primary data which is done by distributing questionnaires and interviews. And the secondary data used in this study is the 2016-2018 annual report turnover from the HRD of PT XYZ Distribution in West Jakarta.

\section{Data Analysis Method}

Data analysis methods used in this study include descriptive analysis of respondents, variable descriptive analysis, validity test, reliability test, coefficient of determination $\left(\mathrm{r}^{2}\right)$, hypothesis testing, path analysis, and inter-dimensional correlation matrices which are used in data processing. using the SPSS program ( Statistical Package for Social Sciences ) 25.0.

\section{RESULT AND DISCUSSION}

\section{A. Descriptive Analysis of Respondents}

The characteristics in this study consisted of age, gender, latest education, and the age of working at PT XYZ Distribution in West Jakarta.

\begin{tabular}{|c|c|c|c|}
\hline No. & Description & Frequency (Person) & Percentage $(\%)$ \\
\hline \multirow[t]{3}{*}{1} & \multicolumn{3}{|c|}{ Gender } \\
\hline & - Male & 198 & 52.69 \\
\hline & - Female & 81 & 47.31 \\
\hline \multirow[t]{5}{*}{2} & \multicolumn{3}{|c|}{ Age } \\
\hline & - Between 18-25 years & 80 & 28.67 \\
\hline & - Between 26 - 30 years & 101 & 36.20 \\
\hline & - Between 31 - 35 years & 66 & 23.66 \\
\hline & - Over 35 Years & 32 & 11.47 \\
\hline \multirow[t]{5}{*}{3} & \multicolumn{3}{|c|}{ Length of work } \\
\hline & - Between $1-3$ years & 267 & 83.54 \\
\hline & - Between 4 - 6 years & 12 & 16.46 \\
\hline & - Between 7 - 9 years & 0 & 00.00 \\
\hline & - Over 9 Years & 0 & 00.00 \\
\hline \multirow[t]{6}{*}{4} & \multicolumn{3}{|c|}{ Level of education } \\
\hline & - Middle school & 0 & 0.00 \\
\hline & - High school & 263 & 75.99 \\
\hline & - Diploma & 16 & 24.01 \\
\hline & - Bachelor degree & 0 & 0.00 \\
\hline & - Others & 0 & 0.00 \\
\hline
\end{tabular}

Table 5: - Characteristics of PT XYZ Distribution Sales Employees in West Jakarta

Source: Researcher Processed Data, 2020

\section{B. Descriptive Analysis of Variables}

Descriptive data provides an overview of the respondent's answers to questions or statements contained in the oner questionnaire and the respondent's responses, namely from the variables of job stress, organizational climate, job satisfaction, and turnover intention. 
ISSN No:-2456-2165

\begin{tabular}{|c|c|c|c|c|c|c|c|c|}
\hline \multirow{2}{*}{ Indicator } & \multicolumn{9}{|c|}{ Respondents' Answers } & \multirow{2}{*}{ Total } & \multirow{2}{*}{ Average } & \multirow{2}{*}{ Std Deviation } \\
\cline { 2 - 8 } & Strongly Disagree & Disagree & Neutral & Agree & Strongly agree & & & \\
\hline X1.1 & 2 & 32 & 151 & 84 & 10 & 279 & 3.24 & 0.73 \\
\hline X1.2 & 4 & 33 & 153 & 87 & 2 & 279 & 3.18 & 0.70 \\
\hline$X 1.3$ & 9 & 58 & 124 & 82 & 6 & 279 & 3.06 & 0.85 \\
\hline X1.4 & 7 & 41 & 143 & 79 & 9 & 279 & 3.15 & 0.80 \\
\hline$X 1.5$ & 12 & 67 & 111 & 82 & 7 & 279 & 3.02 & 0.90 \\
\hline$X 1.6$ & 7 & 73 & 111 & 84 & 4 & 279 & 3.02 & 0.85 \\
\hline$X 1.7$ & 7 & 45 & 139 & 83 & 5 & 279 & 3.12 & 0.79 \\
\hline$X 1.8$ & 7 & 34 & 139 & 93 & 6 & 279 & 3.20 & 0.78 \\
\hline Total & $\mathbf{5 5}$ & $\mathbf{3 8 3}$ & $\mathbf{1 0 7 1}$ & $\mathbf{6 7 4}$ & $\mathbf{4 9}$ & $\mathbf{2 2 3 2}$ & $\mathbf{3 . 1 3}$ & $\mathbf{0 . 6 0}$ \\
\hline Percentage & $\mathbf{2 . 4 6 \%}$ & $\mathbf{1 7 . 1 6 \%}$ & $\mathbf{4 7 . 9 8 \%}$ & $\mathbf{3 0 . 2 0 \%}$ & $\mathbf{2 . 2 0 \%}$ & $\mathbf{1 0 0 . 0 0 \%}$ & & \\
\hline
\end{tabular}

Table 6: - Description of the Results of the Variable Job Stress Questionnaire $\left(\mathrm{X}_{1}\right)$

Source: Researcher Processed Data, 2020

\begin{tabular}{|c|c|c|c|c|c|c|c|c|}
\hline \multirow[b]{2}{*}{ Indicator } & \multicolumn{5}{|c|}{ Respondents' Answers } & \multirow[b]{2}{*}{ Total } & \multirow[b]{2}{*}{ Average } & \multirow{2}{*}{$\begin{array}{c}\text { Std } \\
\text { Deviation }\end{array}$} \\
\hline & $\begin{array}{l}\text { Strongly } \\
\text { Disagree } \\
\end{array}$ & Disagree & Neutral & Agree & $\begin{array}{c}\text { Strongly } \\
\text { agree }\end{array}$ & & & \\
\hline $\mathrm{X} 2.1$ & 15 & 91 & 134 & 33 & 6 & 279 & 2.73 & 0.82 \\
\hline $\mathrm{X} 2.2$ & 17 & 105 & 125 & 24 & 8 & 279 & 2.65 & 0.84 \\
\hline $\mathrm{X} 2.3$ & 14 & 88 & 114 & 49 & 14 & 279 & 2.86 & 0.94 \\
\hline $\mathrm{X} 2.4$ & 7 & 84 & 120 & 55 & 13 & 279 & 2.94 & 0.89 \\
\hline $\mathrm{X} 2.5$ & 12 & 76 & 125 & 55 & 11 & 279 & 2.92 & 0.89 \\
\hline $\mathrm{X} 2.6$ & 11 & 83 & 130 & 47 & 8 & 279 & 2.85 & 0.85 \\
\hline $\mathrm{X} 2.7$ & 11 & 86 & 132 & 42 & 8 & 279 & 2.82 & 0.84 \\
\hline $\mathrm{X} 2.8$ & 13 & 71 & 151 & 37 & 7 & 279 & 2.84 & 0.81 \\
\hline $\mathrm{X} 2.9$ & 8 & 91 & 130 & 41 & 9 & 279 & 2.83 & 0.83 \\
\hline $\mathrm{X} 2.10$ & 5 & 86 & 157 & 29 & 2 & 279 & 2.77 & 0.68 \\
\hline $\mathrm{X} 2.11$ & 5 & 75 & 150 & 42 & 7 & 279 & 2.90 & 0.76 \\
\hline $\mathrm{X} 2.12$ & 8 & 70 & 153 & 45 & 3 & 279 & 2.87 & 0.75 \\
\hline Total & 126 & 1006 & 1621 & 499 & 96 & 3348 & 2.83 & 0.53 \\
\hline Percentage & $3.76 \%$ & $30.05 \%$ & $48.42 \%$ & $14.90 \%$ & $2.87 \%$ & $100.00 \%$ & & \\
\hline
\end{tabular}

Table 7:- Description of the Results of the Questionnaire for Organizational Climate Variables $\left(\mathrm{X}_{2}\right)$ Source: Researcher Processed Data, 2020

\begin{tabular}{|c|c|c|c|c|c|c|c|c|}
\hline \multirow[b]{2}{*}{ Indicator } & \multicolumn{5}{|c|}{ Respondents' Answers } & \multirow[b]{2}{*}{ Total } & \multirow[b]{2}{*}{ Average } & \multirow[b]{2}{*}{$\begin{array}{c}\text { Std } \\
\text { Deviation }\end{array}$} \\
\hline & $\begin{array}{l}\text { Strongly } \\
\text { Disagree }\end{array}$ & Disagree & Neutral & Agree & $\begin{array}{c}\text { Strongly } \\
\text { agree }\end{array}$ & & & \\
\hline Y1.1 & 5 & 68 & 173 & 28 & 5 & 279 & 2.86 & 0.68 \\
\hline Y1.2 & 5 & 76 & 178 & 19 & 1 & 279 & 2.77 & 0.61 \\
\hline Y1.3 & 7 & 68 & 169 & 29 & 6 & 279 & 2.85 & 0.72 \\
\hline Y1.4 & 10 & 65 & 168 & 32 & 4 & 279 & 2.84 & 0.72 \\
\hline Y1.5 & 4 & 65 & 181 & 27 & 2 & 279 & 2.85 & 0.63 \\
\hline Y1.6 & 6 & 58 & 177 & 33 & 5 & 279 & 2.90 & 0.69 \\
\hline Y1.7 & 9 & 62 & 178 & 25 & 5 & 279 & 2.84 & 0.70 \\
\hline Y1.8 & 7 & 63 & 183 & 20 & 6 & 279 & 2.84 & 0.68 \\
\hline Y1.9 & 5 & 78 & 160 & 34 & 2 & 279 & 2.82 & 0.69 \\
\hline Y1.10 & 8 & 78 & 169 & 23 & 1 & 279 & 2.75 & 0.66 \\
\hline Y1.11 & 1 & 94 & 162 & 20 & 2 & 279 & 2.74 & 0.62 \\
\hline Total & 67 & 775 & 1898 & 290 & 39 & 3069 & 2.82 & 0.41 \\
\hline Percentage & $2.18 \%$ & $25.25 \%$ & $61.84 \%$ & $9.45 \%$ & $1.27 \%$ & $100.00 \%$ & & \\
\hline
\end{tabular}

Table 8: - Description of the Results of the Questionnaire for Variable Job Satisfaction ( $\mathrm{Y}_{1}$ ) Source: Researcher Processed Data, 2020 
ISSN No:-2456-2165

\begin{tabular}{|c|c|c|c|c|c|c|c|c|}
\hline \multirow[b]{2}{*}{ Indicator } & \multicolumn{5}{|c|}{ Respondents' Answers } & \multirow[b]{2}{*}{ Total } & \multirow[b]{2}{*}{ Average } & \multirow{2}{*}{$\begin{array}{c}\text { Std } \\
\text { Deviation }\end{array}$} \\
\hline & $\begin{array}{l}\text { Strongly } \\
\text { Disagree }\end{array}$ & Disagree & Neutral & Agree & $\begin{array}{c}\text { Strongly } \\
\text { agree }\end{array}$ & & & \\
\hline Y2.1 & 0 & 2 & 123 & 151 & 3 & 279 & 3.56 & 0.53 \\
\hline Y2.2 & 2 & 4 & 136 & 130 & 7 & 279 & 3.49 & 0.61 \\
\hline Y2.3 & 1 & 5 & 129 & 139 & 5 & 279 & 3.51 & 0.59 \\
\hline $\mathrm{Y} 2.4$ & 1 & 5 & 128 & 143 & 2 & 279 & 3.50 & 0.57 \\
\hline Y2.5 & 0 & 1 & 135 & 138 & 5 & 279 & 3.53 & 0.54 \\
\hline Total & 4 & 17 & 651 & 701 & 22 & 1395 & 3.52 & 0.31 \\
\hline Percentage & $0.29 \%$ & $1.22 \%$ & $46.67 \%$ & $50.25 \%$ & $1.58 \%$ & $100.00 \%$ & & \\
\hline
\end{tabular}

Table 9: - Description of the Results of the Questionnaire for Variable Turnover Intention $\left(\mathrm{Y}_{2}\right)$

Source: Researcher Processed Data, 2020

\section{Validity Test}

Validity states accuracy or preciseness. The higher the accuracy of the data that occurs on the object of research with the data reported by the researcher, the higher the validity of the data. The validity test is carried out using the Pearson Product Moment Correlation, if $r$ count $>r$ table it means valid. If $r$ count $>r$ table with $\alpha=0,05$ then the correlation coefficient is significant. The minimum requirement to be considered suit $\mathrm{g}$ Uhi requirement is if $\mathrm{r}=0,3$.

\begin{tabular}{|c|c|c|c|}
\hline Indicator Codes & r Count & Terms & Information \\
\hline $\mathrm{X} 1.1$ & 0.601 & $>0.30$ & Valid \\
\hline $\mathrm{X} 1.2$ & 0.620 & $>0.30$ & Valid \\
\hline $\mathrm{X} 1.3$ & 0.791 & $>0.30$ & Valid \\
\hline $\mathrm{X} 1.4$ & 0.781 & $>0.30$ & Valid \\
\hline $\mathrm{X} 1.5$ & 0.769 & $>0.30$ & Valid \\
\hline $\mathrm{X} 1.6$ & 0.785 & $>0.30$ & Valid \\
\hline $\mathrm{X} 1.8$ & 0.774 & $>0.30$ & Valid \\
\hline
\end{tabular}

Table 10: - Results of the Validity Test of the Variable Job Stress Indicator $\left(\mathrm{X}_{1}\right)$

Source: Results of analysis using SPSS 25.0

\begin{tabular}{|c|c|c|c|}
\hline Indicator Codes & r Count & Terms & Information \\
\hline $\mathrm{X} 2.1$ & 0.483 & $>0.30$ & Valid \\
\hline $\mathrm{X} 2.2$ & 0.489 & $>0.30$ & Valid \\
\hline $\mathrm{X} 2.3$ & 0.688 & $>0.30$ & Valid \\
\hline $\mathrm{X} 2.4$ & 0.663 & $>0.30$ & Valid \\
\hline $\mathrm{X} 2.5$ & 0.599 & $>0.30$ & Valid \\
\hline $\mathrm{X} 2.6$ & 0.630 & $>0.30$ & Valid \\
\hline $\mathrm{X} 2.7$ & 0.676 & $>0.30$ & Valid \\
\hline $\mathrm{X} 2.8$ & 0.649 & $>0.30$ & Valid \\
\hline $\mathrm{X} 2.9$ & 0.731 & $>0.30$ & Valid \\
\hline $\mathrm{X} 2.10$ & 0.682 & $>0.30$ & Valid \\
\hline $\mathrm{X} 2.11$ & 0.715 & 0.703 & Valid \\
\hline $\mathrm{X} 2.12$ & $* *$ Correlation is significant at the 0.01 level $(2$-tailed). & \\
\hline
\end{tabular}

Table 11: - Results of the Validity Test of Organizational Climate Variable Indicators $\left(\mathrm{X}_{2}\right)$

Source: Results of analysis using SPSS 25.0 


\begin{tabular}{|c|c|c|c|}
\hline Indicator Codes & r Count & Terms & Information \\
\hline Y1.1 & 0.574 & $>0.30$ & Valid \\
\hline Y1.2 & 0.665 & $>0.30$ & Valid \\
\hline Y1.3 & 0.667 & $>0.30$ & Valid \\
\hline Y1.4 & 0.589 & $>0.30$ & Valid \\
\hline Y1.5 & 0.651 & $>0.30$ & Valid \\
\hline Y1.6 & 0.683 & $>0.30$ & Valid \\
\hline Y1.8 & 0.608 & $>0.30$ & Valid \\
\hline Y1.9 & 0.510 & $>0.30$ & Valid \\
\hline Y1.10 & 0.575 & $>0.30$ & Valid \\
\hline Y1.11 & 0.548 & $>0.30$ & Valid \\
\hline & 0.662 & $>0.30$ & \\
\hline
\end{tabular}

Table 12:- Results of the Validity Test of the Variable Indicator Job Satisfaction ( $\left.\mathrm{Y}_{1}\right)$ Source: Results of analysis using SPSS 25.0

\begin{tabular}{|c|c|c|c|}
\hline Indicator Codes & r Count & Terms & Information \\
\hline Y2.1 & 0.541 & $>0.30$ & Valid \\
\hline Y2.2 & 0.582 & $>0.30$ & Valid \\
\hline Y2.3 & 0.561 & $>0.30$ & Valid \\
\hline Y2.4 & 0.502 & $>0.30$ & Valid \\
\hline Y2.5 & 0.535 & $>0.30$ & \\
\hline \multicolumn{2}{r}{} \\
\hline
\end{tabular}

Table 13:- Results of the Validity Test of the Variable Indicator Turnover Intention $\left(\mathrm{Y}_{2}\right)$

Source: Results of analysis using SPSS 25.0

D. Reliability Test

\begin{tabular}{|c|c|c|c|}
\hline Variable & Value Cronbach's Alpha & Terms & Desc \\
\hline Job stress & 0780 & $>0.6$ & Reliable \\
\hline Organizational Climate & 0.757 & $>0.6$ & Reliable \\
\hline Job satisfaction & 0.752 & $>0.6$ & Reliable \\
\hline Turnover Intention & 0.697 & $>0.6$ & Reliable \\
\hline
\end{tabular}

Table 14:- Variable Indicator Reliability Test Results Source: Results of analysis using SPSS 25.0

Table 14 above is the result of the reliability test. The reliability test is carried out by comparing the Cronbach Alpha numbers where the Cronbach Alpha value is at least 0,6 or $\geq 0.6$. The reliability test above $>0,6$, it can be concluded that the reliability test results are above reliable.

\section{E. The coefficient of determination $\left(R^{2}\right)$}

\begin{tabular}{|c|c|c|c|c|}
\hline \multicolumn{5}{|c|}{ Structural Equations 1} \\
\hline \multicolumn{5}{|c|}{ Model Summary ${ }^{b}$} \\
\hline Model & $\mathrm{R}$ & R Square & Adjusted R Square & Std. Error of the Estimate \\
\hline 1 & $.791^{\mathrm{a}}$ & 0.625 & 0.622 & 0.253 \\
\hline \multicolumn{5}{|c|}{ a. Predictors: (Constant), Organizational Climate, Job Stress } \\
\hline \multicolumn{5}{|c|}{ b. Dependent Variable: Job Satisfaction } \\
\hline \multicolumn{5}{|c|}{ Structural Equations 2} \\
\hline \multicolumn{5}{|c|}{ Model Summary $^{\mathbf{b}}$} \\
\hline Model & $\mathrm{R}$ & R Square & Adjusted R Square & Std. Error of the Estimate \\
\hline 1 & $.900^{\mathrm{a}}$ & 0.810 & 0.808 & 0.136 \\
\hline \multicolumn{5}{|c|}{ a. Predictors: (Constant), Job Satisfaction, Organizational Climate, Job Stress } \\
\hline \multicolumn{5}{|c|}{ b. Dependent Variable: Turnover Intention } \\
\hline
\end{tabular}

Table 15:- Results of the $R$-Square Coefficient of Determination

Source: Results of analysis using SPSS 25.0 
Table 15 above can be concluded that the value of Adjusted $R$ Square equation substructure $1=0.622$. While the value of Adjusted $R$ Square for substructure equation $2=0.808$. The rest is influenced by factors other than this research.

$\boldsymbol{\rho} \boldsymbol{\gamma} \boldsymbol{\varepsilon} \mathbf{1}=1-$ Adjuste $\mathrm{R}^{2}=1-0,622=0,378=37,8 \%$

$\boldsymbol{\rho} \boldsymbol{\gamma} \boldsymbol{\varepsilon} \mathbf{2}=1-$ Adjuste $\mathrm{R}^{2}=1-0,808=0,192=19,2 \%$

\section{F. Hypothesis Testing}

> Simultaneous Significance Test (Test $f$ )

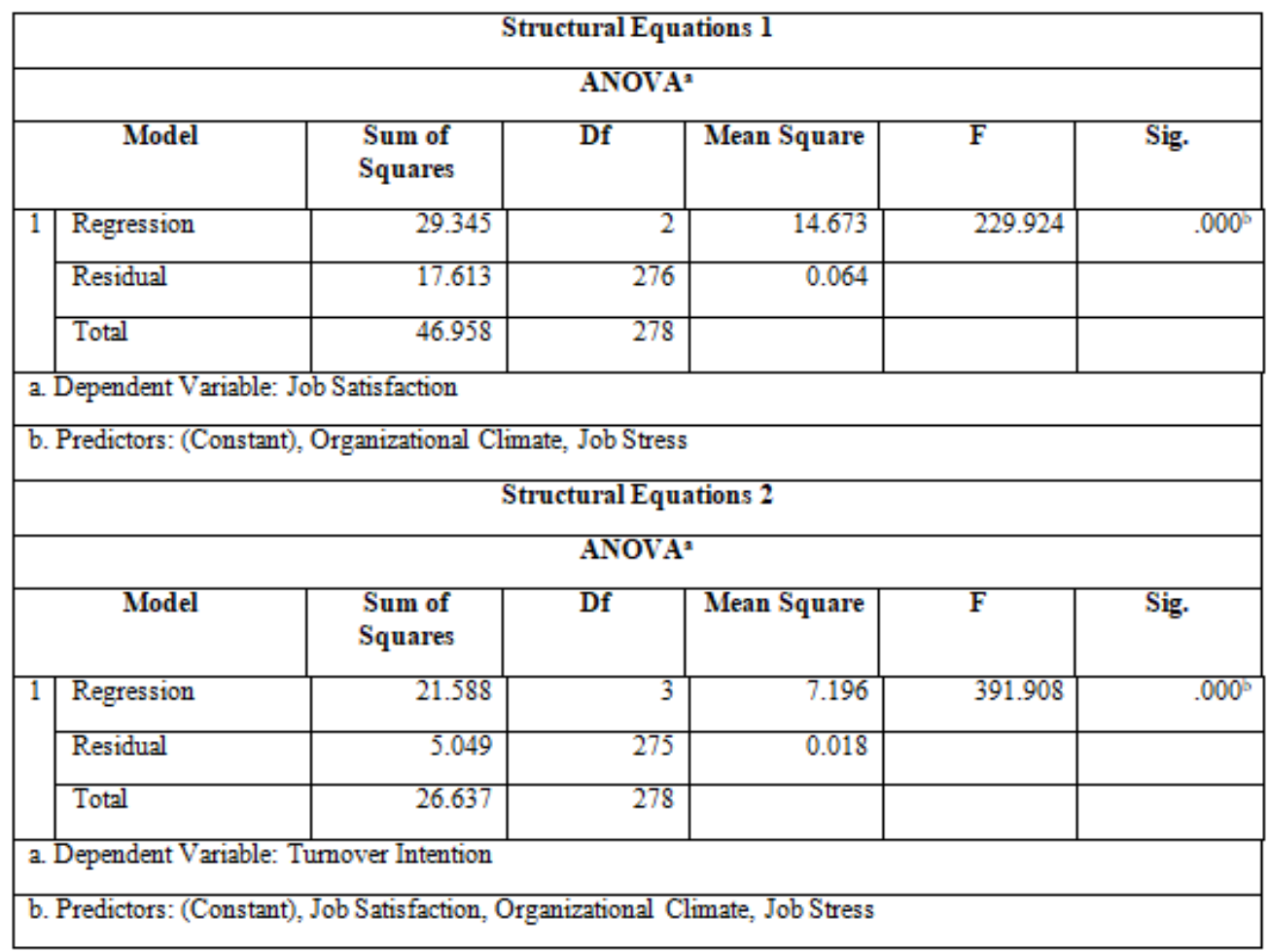

Table 16: - Results of the $F$ Test Analysis

Source: Results of analysis using SPSS 25.0

Table 16 above the test result $\mathrm{u}$ ji $f$ in which $\mathrm{p}$ engujian using a significance level of 0,05 . Simultaneous regression test (Test $f$ ) can be formulated as follows. If Sig. <0, 05 Then H0 is rejected, and Ha is accepted (significant). If Sig. > 0 , 05 Then $\mathrm{H} 0$ is accepted, and $\mathrm{Ha}$ is rejected (not significant). So it can be concluded from table 16 it is known that the value of $\mathrm{F}$ structure 1 $=229.924$, and the value of $\mathrm{Sig} .=0,000$. Thus $\mathrm{H}_{0}$ is rejected, this is the variable Job Stress $\left(\mathrm{X}_{1}\right)$, and Organizational Climate $\left(\mathrm{X}_{2}\right)$ together have a significant effect on Job Satisfaction $\left(\mathrm{Y}_{1}\right)$. Meanwhile, it is known that the value of $\mathrm{F}$ structure $2=$ 391.908 , and the value of $\mathrm{Sig} .=0,000$. Thus $\mathrm{H}_{0}$ is rejected, this is the variable Job Stress $\left(\mathrm{X}_{1}\right)$, Organizational Climate $\left(\mathrm{X}_{2}\right)$, and Job Satisfaction $\left(\mathrm{Y}_{1}\right)$ together have a significant effect on the Turnover Intention $\left(\mathrm{Y}_{2}\right)$ variable .

\section{Hypothesis Test ( $t$ test )}

\section{Coefficients $^{\mathrm{a}}$}

\begin{tabular}{|c|c|c|c|c|c|c|}
\hline & \multirow{2}{*}{ Model } & \multicolumn{2}{|c|}{ Unstandardized Coefficients } & \multirow{2}{*}{$\mathbf{t}$} & \multirow{2}{*}{ Sig. } & \multirow{2}{*}{ Desc } \\
\hline & & B & Std. Error & & & \\
\hline \multirow[t]{3}{*}{1} & (Constant) & 3.377 & 0,131 & 25.820 & 0.000 & \\
\hline & Job stress & -0.431 & 0.026 & -16.468 & 0.000 & $\begin{array}{c}\text { Significant } \\
\text { Negative Effect }\end{array}$ \\
\hline & Organizational Climate & 0,280 & 0.030 & 9.499 & 0.000 & $\begin{array}{c}\text { Significant } \\
\text { Positive Effect }\end{array}$ \\
\hline \multicolumn{6}{|c|}{ a. Dependent Variable: Job satisfaction } & \\
\hline
\end{tabular}




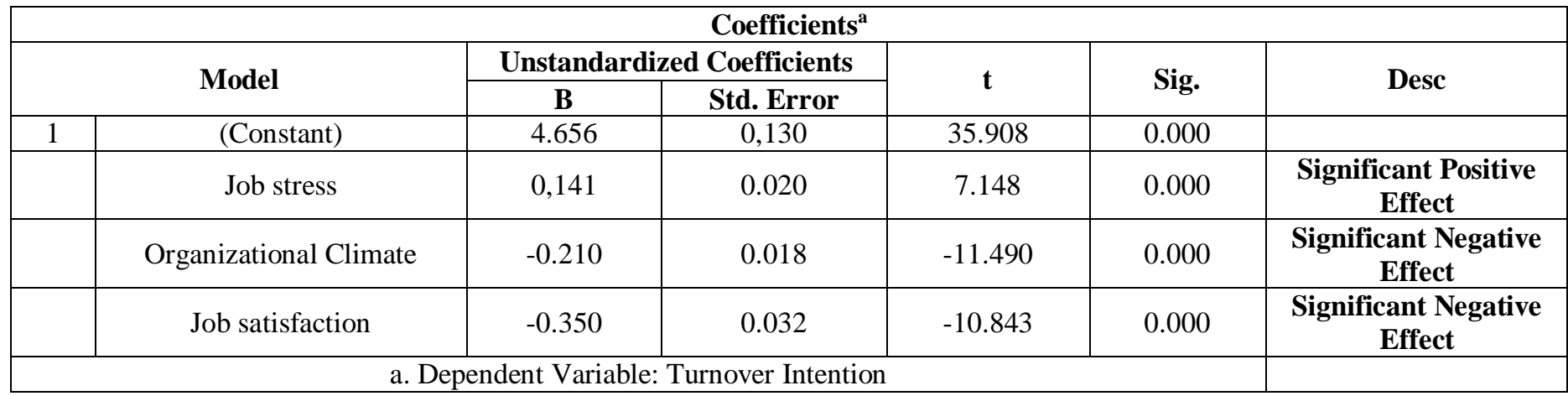

Table 17: - Results of the t Test Analysis

Source: Results of analysis using SPSS 25.0

Based on the results of data management, the $t$ test results are as follows:

- Job stress $\left(\mathrm{X}_{1}\right)$ with job satisfaction $\left(\mathrm{Y}_{1}\right)$ is significant by $\mathrm{t}$-test amounted to $-16.468(\mathrm{t}$ count $<$ t table $(\mathrm{df}=275)=-1,97)$ and the value of Sig . $=0.000$. Thus the hypothesis $\mathrm{H}_{1}$ in this study which states that "Job Stress $\left(\mathrm{X}_{1}\right)$ has a significant effect on Job Satisfaction ( $\left.\mathrm{Y}_{1}\right)$ Employees " is accepted .

- Organizational Climate $\left(\mathrm{X}_{2}\right)$ with job satisfaction $\left(\mathrm{Y}_{1}\right)$ is significant by t-test amounted to 9.499 ( $\mathrm{t}$ count $>\mathrm{t}$ table $(\mathrm{df}=275)=1,97)$ and the value of Sig. $=0.000$. Thus the hypothesis $\mathrm{H}_{2}$ in this study which states that "Organizational Climate $\left(\mathrm{X}_{2}\right)$ has a significant effect on Job Satisfaction ( $\left.\mathrm{Y}_{1}\right)$ Employees " is accepted.

- Job Stress $\left(\mathrm{X}_{1}\right)$ with Turnover Intention $\left(\mathrm{Y}_{2}\right)$ is significant by t-test amounted to 7.148 $(\mathrm{t}$ count $>\mathrm{t}$ table $(\mathrm{df}=275)=1,97)$ and the value of Sig . $=0.000$. Thus the hypothesis $\mathrm{H}_{3}$ in this study which states that "Job Stress $\left(\mathrm{X}_{1}\right)$ has a significant effect on Employee Turnover Intention $\left(\mathrm{Y}_{2}\right)$ " is accepted.

- Organizational Climate $\left(\mathrm{X}_{2}\right)$ with Turnover Intention $\left(\mathrm{Y}_{2}\right)$ is significant with a $\mathrm{t}$-count equal to $11.490(\mathrm{t}$ count $<\mathrm{t}$ table $(\mathrm{df}=275)=-1,97)$ and the value of $\mathrm{Sig} .=0.000$. Thus the hypothesis $\mathrm{H}_{4}$ in this study which states that "Organizational Climate $\left(\mathrm{X}_{2}\right)$ has a significant effect on Employee Turnover Intention $\left(\mathrm{Y}_{2}\right)$ " is accepted .

- Job satisfaction ( $\left.\quad \mathrm{Y}_{1}\right)$ with Turnover Intention $\left(\mathrm{Y}_{2}\right)$ is significant by t-test amounted to $10.843(\mathrm{t}$ count $<\mathrm{t}$ table $(\mathrm{df}=275)=-1,97)$ and the value of $\mathrm{Sig} .=0.000$. Thus the hypothesis $\mathrm{H}_{5}$ in this study which states that "Job Satisfaction $\left(\mathrm{Y}_{1}\right)$ has a significant effect on Employee Turnover Intention $\left(\mathrm{Y}_{2}\right)$ " is accepted .

Interpretation and Testing the hypothesis and the value of $\mathrm{R}^{2}$ are as follows:

$Y_{1}=3,377-0,431 X_{1}+0,280 X_{2}+0,378 e$;

$Y_{2}=4,656+0,141 X_{1}-0,210 X_{2}-0,350 Y_{1}+0,192 e$

G. Path Analysis ( Path Analysis)

\begin{tabular}{|l|c|c|c|c|c|c|c|}
\hline \multirow{3}{*}{ Variable } & \multicolumn{2}{|c|}{ Y1 } & \multicolumn{2}{c|}{ Y2 } & \multicolumn{2}{c|}{$\begin{array}{c}\text { Indirect Effect } \\
\text { Analysis }\end{array}$} & \multirow{2}{*}{ Desc } \\
\cline { 2 - 8 } & $\begin{array}{l}\text { Unstandardized } \\
\text { Coefficient }(\beta)\end{array}$ & Std. Error & $\begin{array}{l}\text { Unstandardized } \\
\text { Coefficient }(\beta)\end{array}$ & Std. Error & $\begin{array}{l}\text { Don't } \\
\text { count }\end{array}$ & Coefficient & \\
\hline Job stress & -0.431 & 0.026 & 0.141 & 0.020 & 9,044 & 0.151 & effect \\
\hline $\begin{array}{l}\text { Organizational } \\
\text { Climate }\end{array}$ & 0.280 & 0.030 & $-0,210$ & 0.018 & $-7,128$ & -0.098 & effect \\
\hline Job satisfaction & - & - & -0.350 & 0.032 & - & & - \\
\hline
\end{tabular}

Table 18: - Path Analysis Calculation Regression Test Results Source: Results of analysis using SPSS 25.0

To calculate the indirect effect, you can use the Sobel test $t=\frac{a b}{S a b}$ formula where

$$
S_{a b}=\sqrt{\left(b^{2} \times S_{a}^{2}\right)+\left(a^{2} \times S_{b}^{2}\right)+\left(S_{a}^{2} \times S_{b}^{2}\right)}
$$

based on table 17 it can be interpreted as follows:
Job Stress Variable (X 1 ) on Turnover Intention (Y 2 ) Through Job Satisfaction (Y 1 ), the t-count value (Job Stress) $==\frac{-0,431 X-0,350}{0,0008}=9,044$, where $\beta$ X $1=-0.431$ $\mathrm{X}-0.350=0,1509$, and $\mathrm{S} 12=0.00008$. Thus the $\mathrm{t}-$ count value is $9.044(\mathrm{t}$-count $>\mathrm{t}$-table $(\mathrm{df}=275)=1.97)$, and the coefficient value is positive, which is 0.150 which indicates that the direction of the relationship between Job Stress (X1) and Turnover Intention (Y 2 ) through Job Satisfaction (Y 1 ) is positive and 
influential or Job Satisfaction reduces the Relationship between Job Stress and Turnover Intention.

$>$ Organizational Climate Variable $\left(\mathrm{X}_{2}\right)$ on Turnover Intention $\left(\mathrm{Y}_{2}\right)$ Through Job Satisfaction $\left(\mathrm{Y}_{1}\right)$, the $\mathrm{t}$ count value (Organizational Climate) $=\frac{0,280 X-0,350}{0,0009}=$ 7,127 , where $\beta X_{1=0,280 X}-0,350=-0,098$, and $S_{12}=$ 0.00009 . Thus the $\mathrm{t}$-count value is -7.127 ( $\mathrm{t}$-count $<-\mathrm{t}$ table $(\mathrm{df}=275)=-1.97)$, and the coefficient value is negative, which is -0.098 which indicates that the direction of the relationship between Organizational
$\left(\mathrm{X}_{2}\right)$ towards Turnover Intention $\left(\mathrm{Y}_{2}\right)$ through Job Satisfaction $\left(\mathrm{Y}_{1}\right)$ is negative and influential or Job Satisfaction reduces the Relationship between Organizational Climate and Turnover Intention .

\section{H. Matrix of Inter-Dimensional \\ $>$ Correlation}

Based on the results of the inter-dimensional correlation matrix testing, processed using the anatomical analysis of SPSS 25.0 shows the table 19:

\begin{tabular}{|c|c|c|c|c|c|c|c|c|c|}
\hline \multicolumn{10}{|c|}{ Correlation } \\
\hline & & \multicolumn{5}{|c|}{ Job Satisfaction (Y1) } & \multicolumn{3}{|c|}{ Turnover Intention (Y2) } \\
\hline & & $\begin{array}{c}.1 \\
\text { Transfer } \\
\text { Of } \\
\text { Employees }\end{array}$ & $\begin{array}{c}3.2 \text { Absence } \\
\text { Rate From } \\
\text { Work }\end{array}$ & $3.3 \mathrm{Age}$ & $\begin{array}{l}\text { 3.4 Job } \\
\text { Level }\end{array}$ & $\begin{array}{l}3.5 \text { Company } \\
\text { Organizational } \\
\text { Size }\end{array}$ & $\begin{array}{c}4.1 \\
\text { Thoughts } \\
\text { Of } \\
\text { Quitting } \\
\text { Work }\end{array}$ & $\begin{array}{c}4.2 \\
\text { Desire } \\
\text { To Leave }\end{array}$ & $\begin{array}{l}\text { 4.3 Desire } \\
\text { To Find } \\
\text { Another } \\
\text { Job }\end{array}$ \\
\hline \multirow{4}{*}{ Job Stress (X1) } & $\begin{array}{l}\text { 1.1 Work } \\
\text { Demands }\end{array}$ & $-0,317$ & $-0,432$ & $-0,388$ & $-0,351$ & $-0,434$ & 0,286 & 0,408 & 0,401 \\
\hline & 1.2 Role Demands & $-0,513$ & $-0,475$ & $-0,504$ & $-0,440$ & $-0,469$ & 0,415 & 0,492 & 0,400 \\
\hline & $\begin{array}{l}\text { 1.3 Organizational } \\
\text { Structure }\end{array}$ & $-0,422$ & $-0,466$ & $-0,491$ & $-0,380$ & $-0,457$ & 0,389 & 0,454 & 0,340 \\
\hline & $\begin{array}{l}\text { 1.4 The Attitude } \\
\text { Of The Leader }\end{array}$ & $-0,468$ & $-0,496$ & $-0,500$ & $-0,380$ & $-0,422$ & 0,404 & 0,430 & 0,311 \\
\hline \multirow{6}{*}{$\begin{array}{l}\text { Organizational } \\
\text { climate (X2) }\end{array}$} & 2.1 Structure & 0,252 & 0,179 & 0,202 & 0,148 & 0,384 & $-0,139$ & $-0,357$ & $-0,418$ \\
\hline & $\begin{array}{l}\text { 2.2 Standard- } \\
\text { Standard }\end{array}$ & 0,257 & 0,312 & 0,365 & 0,235 & 0,313 & $-0,426$ & $-0,433$ & $-0,204$ \\
\hline & 2.3 Responsible & 0,317 & 0,280 & 0,324 & 0,259 & 0,247 & $-0,497$ & $-0,387$ & $-0,173$ \\
\hline & 2.4 Award & 0,271 & 0,283 & 0,274 & 0,219 & 0,312 & $-0,362$ & $-0,411$ & $-0,292$ \\
\hline & 2.5 Support & 0,361 & 0,312 & 0,322 & 0,259 & 0,401 & $-0,400$ & $-0,487$ & $-0,372$ \\
\hline & 2.6 Commitment & 0,299 & 0,264 & 0,327 & 0,249 & 0,384 & $-0,467$ & $-0,440$ & $-0,266$ \\
\hline \multirow{6}{*}{$\begin{array}{c}\text { Job satisfaction } \\
\text { (Y1) }\end{array}$} & $\begin{array}{l}3.1 \text { Transfer Of } \\
\text { Employees }\end{array}$ & - & - & - & - & - & $-0,459$ & $-0,514$ & $-0,338$ \\
\hline & $\begin{array}{l}3.2 \text { Absence Rate } \\
\text { From Work }\end{array}$ & - & - & - & - & - & $-0,485$ & $-0,552$ & $-0,397$ \\
\hline & 3.3 Age & - & - & - & - & - & $-0,499$ & $-0,520$ & $-0,338$ \\
\hline & 3.4 Job Level & - & - & - & - & - & $-0,393$ & $-0,469$ & $-0,285$ \\
\hline & $\begin{array}{l}3.5 \text { Company } \\
\text { Organizational } \\
\text { Size }\end{array}$ & - & - & - & - & - & $-0,428$ & $-0,593$ & $-0,505$ \\
\hline & $\mathbf{N}$ & 279 & 279 & 279 & 279 & 279 & 279 & 279 & 279 \\
\hline
\end{tabular}

Table 19: - Inter-dimensional correlation matrix Test Results Source: Results of analysis using SPSS 25.0

- The Job Stress Variable $\left(\mathrm{X}_{1}\right)$ on the Job Satisfaction Variable ( $\left.\mathrm{Y}_{1}\right)$ above shows that the greatest correlation value between the dimensions in the Job Stress variable $\left(\mathrm{X}_{1}\right)$ on the Job Satisfaction variable $\left(\mathrm{Y}_{1}\right)$ is the $\mathrm{X} 1.2$ Role Demands with dimension Y1.1 Employee Transfer is $-0,513$. This explains that the $\mathrm{X} 1.2$ dimension of reducing Role Demands in the Job Stress variable is needed to support the increase in Job Satisfaction $\left(\mathrm{Y}_{1}\right)$, especially in the dimension of Employee Transfer.

- Variable Organizational Climate $\left(\mathrm{X}_{2}\right)$ to the Job Satisfaction Variable $\left(\mathrm{Y}_{1}\right)$ above it is known that the greatest correlation value between the dimensions in the Organizational Climate variable $\left(\mathrm{X}_{2}\right)$ on the Job Satisfaction variable $\left(\mathrm{Y}_{1}\right)$ is $\mathrm{X} 2.5$ Support with dimensions Y 1.1 Size Company Organization that is 0.401 , and in the category of medium level of relationship. This explains that the dimension of X2.5 Support in the Organizational Climate variable is needed for any increase in Job Satisfaction
( $\left.\mathrm{Y}_{1}\right)$, especially in the dimension of Company Organization Size.

- The Job Stress Variable $\left(\mathrm{X}_{1}\right)$ on the Turnover Intention $\left(\mathrm{Y}_{2}\right)$ Variable above shows that the greatest correlation value between the dimensions in the Work Stress variable $\left(\mathrm{X}_{1}\right)$ on the Turnover Intention $\left(\mathrm{Y}_{2}\right)$ variable is the $\mathrm{X} 1.2$ Role Demands with dimensions Y 2.2 desire to Leave is 0.492 , and in the category of medium level of relationship. This explains that each increase in the dimension of X1.2 Role Demands in the Job Stress variable will support the increase in Turnover Intention ( $\left.\mathrm{Y}_{2}\right)$, especially in the dimension of Desire to Leave.

- Variable Organizational Climate $\left(\mathrm{X}_{2}\right)$ to the Turnover Intention $\left(\mathrm{Y}_{2}\right)$ variable above, it is known that the greatest correlation value between the dimensions in the Organizational Climate variable $\left(\mathrm{X}_{2}\right)$ to the Turnover Intention variable $\left(\mathrm{Y}_{2}\right)$ is $\mathrm{X} 2.3$ Responsibility with dimension Y2 .1 Mind to Stop, namely -0.497 , and it is included in the category of moderate level of 
relationship. This explains that every increase in the X2.3 Responsibility dimension in the Organizational Climate variable is required for every reduction in Turnover Intention $\left(\mathrm{Y}_{2}\right)$ especially in the Mind to Stop dimension.

- Job Satisfaction variable $\left(\mathrm{Y}_{2}\right)$ of the variable Turnover Intention $\left(\mathrm{Y}_{2}\right)$ above in mind that the greatest correlation value between dimensions in job satisfaction variable $\left(\mathrm{Y}_{1}\right)$ to variable Turnover Intention $\left(\mathrm{Y}_{2}\right)$ is the dimension Y 1.1 Level attendance Working with dimension Y 2.2 desire to Leave is -0.552 , and in the category of medium level of relationship. This explains that the Y1.1 Dimension of Job Attendance in the Job Satisfaction variable is needed for any reduction in Turnover Intention ( $\left.\mathrm{Y}_{2}\right)$, especially in the Willing to Leave dimension.

\section{Discussion}

\section{$>$ Effect of Job Stress $\left(X_{I}\right)$ on Job Satisfaction $\left(Y_{I}\right)$}

Based on the research results Stress Job $\left(X_{1}\right)$ a significant negative effect on job satisfaction $\left(\mathrm{Y}_{2}\right)$. This means that the job stress experienced by employees of PT XYZ Distribution in West Jakarta. can affect how they feel, whether it's about the job or the results they receive. Stress is a major problem at work which is closely related to satisfaction. Lack of satisfaction can be a source of stress. The results of this study are in line with research previously conducted by Muhammad Irfan Nasution (2017) which proves that the relationship between job stress has a significant effect on job satisfaction.

\section{> The Effect of Organizational Climate $\left(\mathrm{X}_{2}\right)$ on Job Satisfaction $\left(Y_{2}\right)$ \\ Based on research results Organizational Climate} $\left(\mathrm{X}_{2}\right)$ has a positive and significant effect on Job Satisfaction $\left(\mathrm{Y}_{2}\right)$. Organizational climate is the quality of the organization's internal environment that is relatively ongoing, experienced by members of the organization and influencing their behavior and can be described in one characteristic or organizational nature (Taiguri and Litwin in Wirawan, 2007: 65). This shows that when the company has a clear organization and has the responsibility of each employee, this can be an additional value for the company to assess the employee's job satisfaction. The results of this study are in line with research previously conducted by Andi Caezar To Tadampali, Abdurrahman Hadi, Rudi Salam (2016) which proved that the relationship between organizational climate has a significant effect on job satisfaction .

\section{$>$ Effect of Job Stress $\left(X_{1}\right)$ on Turnover Intention $\left(Y_{l}\right)$}

Based on the results of the research that Job Stress $\left(\mathrm{X}_{1}\right)$ has a positive and significant effect on Turnover Intention ( $\left.\mathrm{Y}_{1}\right)$. According to Hasibuan (2012: 204) work stress has several profound factors when employees themselves are not comfortable in the company, namely excessive workload, unfair work pressure, and too low compensation for services. This shows that employees of PT XYZ Distribution in West Jakarta when experiencing work stress at work are characterized by the factors above and employees also try to want to move to another company. The results of this study are in line with research previously conducted by Charles Bohlen Purba and Achmad Farizki (2020), proving that the relationship of job stress has a positive and significant effect on turnover intention .

\section{$>$ The Effect of Organizational Climate $\left(X_{2}\right)$ on Turnover Intention $\left(Y_{1}\right)$}

Based on research results, Organizational Climate $\left(\mathrm{X}_{2}\right)$ has a negative and significant effect on Turnover Intention $\left(\mathrm{Y}_{2}\right)$. According to Melky (2015) the desire to change jobs or the desire to leave an organization is because the employee does not feel comfortable and intends to move to an even more comfortable organization. This shows that when the work organization environment is not in line with employees, the employee's desire to find work can occur in a company. The results of this study are in line with research previously conducted by I Gede Putra Arnanta and I Wayan Mudiartha Utama (2017), proving that the relationship between organizational climate has a significant effect on turnover intention .

\section{$>$ Effect Job Satisfaction $\left(Y_{2}\right)$ on Turnover Intention $\left(Y_{1}\right)$ \\ Based on the results of research that job satisfaction $\left(\mathrm{Y}_{2}\right)$ significant negative effect on Turnover} Intention $\left(\mathrm{Y}_{1}\right)$. This shows according to Sutrisno (2016) that high job satisfaction will not make turnover low, but when employees are not satisfied with their work, the turnover in the company itself will be high, which is where there are several negative factors such as social aspects that cause dissatisfaction. work. The results of this study are in line with research previously conducted by Muhammad Khaidir (2016), proving that the relationship between job satisfaction has a significant effect on turnover intention .

\section{$>$ Effect of Job Stress $\left(X_{1}\right)$ on Turnover Intention $\left(Y_{1}\right)$ through Job Satisfaction $\left(Y_{2}\right)$}

Based on the research results, Job Stress $\left(\mathrm{X}_{1}\right)$ on Turnover Intention $\left(\mathrm{Y}_{1}\right)$ through Job Satisfaction $\left(\mathrm{Y}_{2}\right)$ is positive or Job Satisfaction reduces the Relationship between Job Stress and Turnover Intention. This shows that there is an influence when the working environment conditions are not good which causes work stress in the company, causing dissatisfaction in work which in turn can lead to actual turnover. The results of this study are in line with research previously conducted by Novy Fitria (2014) which proves that the relationship between job stress and turnover intention through job satisfaction has an effect.

\section{Influence of Organizational Climate $\left(\mathrm{X}_{2}\right)$ on Turnover Intention $\left(Y_{1}\right)$ through Job Satisfaction $\left(Y_{2}\right)$}

Based on the research results, Organizational Climate (X2) on Turnover Intention (Y1) through Job Satisfaction (Y2) is influential. And it shows that the direction of the relationship between Organizational Climate (X2) and Turnover Intention (Y1) through Job Satisfaction (Y2) is negative or Job Satisfaction reduces the Relationship between Organizational Climate and Turnover Intention. The results of this study are in line with research previously 
conducted by Elok Farida, Wiyarni (2019), proving that the relationship between organizational climate and turnover intention through job satisfaction has an influence.

\section{CONCLUSIONS AND SUGGESTIONS}

\section{A. Conclusion}

Based on the results of the research and discussion that has been done, it can be concluded as follows:

$>$ Job stress variable has a negative and significant effect on Job Satisfaction.

$>$ Organizational climate variable has a positive and significant effect on job satisfaction .

$>$ Job stress variable has a positive and significant effect on Turnover Intention .

$>$ Organizational Climate variable has a negative and significant effect on Turnover Intention .

$>$ Job Satisfaction Variable has a negative and significant effect on Turnover Intention .

$>$ Job stress variable has a positive and significant effect on Turnover Intention through Job Satisfaction.

$>$ Organizational Climate variable has a negative and significant effect on Turnover Intention through Job Satisfaction.

\section{B. Suggestions}

Based on the results of the discussion analysis and some of the conclusions above, the suggestions that can be given to complement the results of this study are as follows:

$>$ Job stress has a negative effect on job satisfaction, so it is suggested that companies pay more attention to employees to reduce work stress through role guidance. Where in this role guidance, namely limiting the target load so that it is not excessive and the boss does not put too much pressure on employees because of the taregt burden. If you limit the target load, employees do not have the thought of moving employees and job satisfaction is minimal in the company.

> Organizational climate has a positive effect on job satisfaction. With the above conclusions, the company must maintain a good organizational climate. This can be done while still giving full responsibility to employees to solve problems related to work tasks in completing work, providing support to be able to develop again, and giving employees the opportunity to convey ideas or suggestions for the progress of the company.

$>$ Job stress has a positive effect on turnover intention, so it is advisable to have programs that can reduce employee stress, either directly or indirectly. Such as giving awards to employees who excel and paying attention to the physical and psychological conditions of employees, reducing excessive target burdens, it is best to pay attention to the welfare of employees. It is hoped that these programs can control the level of work stress on employees so that turnover can be prevented.

$>$ Organizational climate has a negative effect on turnover intention, so it is recommended that companies pay more attention to the welfare of their employees by providing rewards, compensation, allowances, or additional bonuses that need to be done to provide comfort, clear responsibility, and increase employee motivation in order to reduce turnover intention.

$>$ Job satisfaction negatively affect t erhadap turnover intention, it is recommended that companies provide to employees refreshing sales each year, so that not too much workload related to their work every day. And also pay attention to the job duties assigned to each employee or create a work environment where safety is more important, so that employees feel satisfied and can reduce the desire to leave.

$>$ Job stress has a positive effect on turnover intention through job satisfaction, so it is suggested to improve the system of distribution of labor evenly according to ability, as well as a balanced target load by looking at the level of length of work in the company. After that, deepen the training or review the employees with the aim that employees have better endurance so that the work itself becomes more enjoyable and provides employee satisfaction, so that it can reduce turnover itself.

$>$ Organizational climate has a negative effect on turnover intention through job satisfaction, so it is suggested that responsibilities should be fully clear and rewards / rewards should also be added in order to provide more satisfaction to employees. And will minimize the turnover itself.

$>$ Expectations of the authors that further research might explore more related variables that affect turnover intention and job satisfaction. Because there are still many other factors that can theoretically affect turnover intention through job satisfaction. Therefore, there needs to be further research on other factors that affect employee job satisfaction which are not examined by the author.

\section{REFERENCES}

[1]. Andi Caezar To Tadampali, Abdurrahman Hadi, Rudi Salam. Pengaruh Iklim Organisasi Terhadap Turnover Intention Melalui Kepuasan Kerja Sebagai Variabel Intervening Pada Pt Bank Sulselbar. Jurnal Adminitrasi Publik, Vol. 6 No.2 Thn 2016.

[2]. Charles Bohlen Purba, Achmad Farizki. The Influence Of Job Stress, Organizational Climate And Job Environment On Employee Turnover Intention. International Journal of Business Marketing and Management (IJBMM) Volume 5 Issue 2 January 2020, P.P. 15-22 ISSN: 2456-4559.

[3]. Elok Farida, Wiyarni. The Effect of Organizational Climate and Job Stress On Turnover Intention with Job Satisfaction as An Intervening Variabel (Case Study : PT. Grahamegaria Surabaya, East Java, Indonesia). International Journal of Business Marketing and Management (IJBMM) Volume 4 Issue 4 April 2019, P.P. 01-07 ISSN: 2456-4559.

[4]. Fitri, Novy. Pengaruh Stress Kerja dan Iklim Organisasi terhadap Turnover Intention dengan Kepuasan Kerja sebagai Variabel Intervening pada Perawat RS X di Surabaya. Tesis 2014. 
[5]. Hasibuan, Malayu S.P. Manajemen: Dasar, Pengertian dan Masalah. Edisi Revisi. Jakarta : PT. Bumi Aksara; 2012.

[6]. I Gede Putra Arnanta, I Wayan Mudiartha Utama. Pengaruh Stres Kerja, Kepuasan Kerja Dan Iklim Organisasi Terhadap Turnover Intention Karyawan Cv. Dharma Siadja. E-Jurnal Manajemen Unud, Vol. 6, No. 6, 2017 : 3314-3341 ISSN : 2302-8912.

[7]. Luthans, Fred. Perilaku Organisasi, (Alih Bahasa V.A Yuwono, dkk), Edisi Bahasa Indonesia, Yogyakarta; 2014.

[8]. Malayu, S.P.H. Manajemen Sumber Daya Manusia. Edisi Revisi. Cetakan Kelima belas. Jakarta. Bumi Aksara; 2011.

[9]. Melky Y. Organisasi Terhadap Intensi Pindah Kerja (Turnover Intention) Karyawan PT . Rejeki Abadi Sakti Samarinda. Ejournal Psikologi, 3 (3), 694-707; 2015.

[10]. Muhammad Khaidir. Pengaruh Stres Kerja, Kompensasi Dan Kepuasan Kerja Terhadap Turnover Intention Studi Pada Karyawan Kontrak Pt. Gagah Satria Manunggal Banjarmasin. Jurnal Wawasan Manajemen, Vol. 4, Nomor 3, Oktober 2016.

[11]. Muhammad Irfan Nasution. Pengaruh Stres Kerja, Kepuasan Kerja Dan Komitmen Organisasi Terhadap Turnover Intention Medical Representative. Jurnal Ilmiah Manajemen, Volume VII, No. 3, Okt 2017.

[12]. Norita. Pengaruh kompensasi dan loyalitas karyawan terhadap intensi turnover di PT. Eramart Group Samarinda. E-journal psikologi universitas Samarinda, Vol. 5, No.2. pp: 1-10; 2014.

[13]. Oktarini Putri Andini, Bambang Swasto Sunuharyo, Hamidah Nayati Utami. Pengaruh Kepuasan Kerja Terhadap Stres Kerja Dan Turnover Intention Karyawan (Studi Pada Karyawan Pt Indolakto Factorypandaan). Jurnal Administrasi Bisnis (JAB)|Vol. 54 No. 1 Januari 2018.

[14]. Robbins, P. Stephen \& Judge, Timothy A. Perilaku Organisasi. Buku 1. Jakarta. Salemba Empat; 2008.

[15]. Schwepker, Charles H. Ethical climate's relationship to job satisfaction, organizational commitment, and turnover intention in the salesforce. Journal of Business Research, Volume 54, Issue 1, Pages 39-52; 2001.

[16]. Sutrisno, Edi . Manajemen Sumber Daya Manusia. Kencana. Jakarta; 2011.

[17]. Tantra, M. S., \& Larasat. Faktor-Faktor Sosial yang Mempengaruhi Stres Kerja Social Factors Affecting Job Stress. Jurnal Majority, 4(9), 58-63; 2015.

[18]. Wirawan. Budaya Organisasi dan Iklim Organisasi: Teori Aplikasi dan Penelitian. Jakarta: Salemba Empat; 2007. 